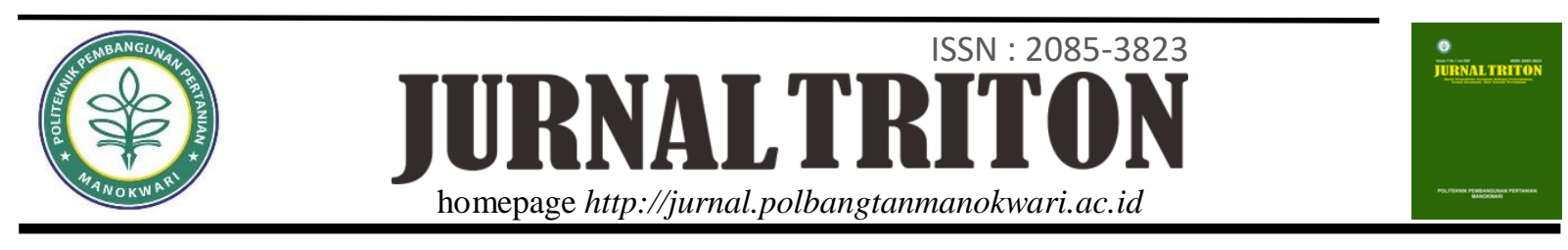

\title{
Aplikasi Pupuk Organik Cair dari Limbah Pertanian dan Perumahan terhadap Produktivitas Kedelai
}

Elrisa Ramadhani ${ }^{1}$, Mahmudah ${ }^{2 *}$

${ }^{1,2}$ Prodi Penyuluhan Pertanian Berkelanjutan, Jurusan Pertanian, Politeknik Pembangunan Pertanian Medan

\begin{tabular}{l}
\hline \multicolumn{1}{c}{ ARTIKEL INFO } \\
\hline Sejarah artikel \\
Diterima 14/06/2020 \\
Diterima dalam bentuk revisi 25/06/2020 \\
Diterima dan disetujui 26/06/2020 \\
Tersedia online 30/06/2020 \\
\hline Kata kunci : \\
Air cucian beras \\
Kedelai \\
Limbah sayuran \\
POC \\
Produktivitas \\
\hline
\end{tabular}

\begin{abstract}
ABSTRAK
Kualitas tanah pertanian sudah semakin berkurang akibat banyaknya penggunaan pupuk kimia. Usaha peningkatan produktivitas tanaman pangan khususnya kedelai juga semakin ditingkatkan. Limbah pertanian dan perumahan juga semakin banyak. Aplikasi Pupuk Organik Cair dari limbah pertanian dan perumahan terhadap produktivitas kedelai dilakukan dengan tujuan untuk membantu perbaikan struktur fisik dan kimia tanah yang juga dapat meningkatkan produktivitas kedelai dengan memanfaatkan Pupuk Organik Cair yang berasal dari limbah pertanian dan perumahan. Penelitian ini menggunakan Rancangan Acak Lengkap Non Faktorial dengan masing - masing perlakuan 3 ulangan, terdiri dari tujuh perlakuan terhadap beberapa Pupuk Organik Cair, yaitu POC berasal dari sisa sayuran + air beras, POC berasal dari eceng gondok + air beras, POC berasal dari sisa makanan dapur, POC berasal dari batang pisang + air beras, POC berasal dari batang pisang, POC berasal dari eceng gondok, dan POC berasal dari sisa sayuran, variabel yang diamati yaitu tinggi tanaman, jumlah daun dan jumlah polong per tanaman. Dilaksanakan di lahan praktik kampus Politeknik Pembangunan Pertanian Medan, mulai bulan Oktober 2019-Januari 2020. Dari hasil penelitian diperoleh bahwa penggunaan POC yang berasal dari campuran limbah sayuran dan air cucian beras memberikan hasil yang lebih baik terhadap pertumbuhan tinggi tanaman, jumlah daun dan jumlah polong tanaman kedelai, dengan nilai pada 4 MST, tinggi tanaman $49 \mathrm{~cm}$, jumlah daun 49 helai dan 213,7 jumlah polong.
\end{abstract}

(C) 2020 Politeknik Pembangunan Pertanian Manokwari

*Email Penulis Korespondensi : elrisa.ramadhani@gmail.com

elrisa.ramadhani@gmail.com¹, mudah_1080@yahoo.com² 


\section{ABSTRACT}

Agricultural land quality has been reduced due to the many uses of chemical fertilizers. Efforts to increase the productivity of food crops especially soy are also increasingly improved. Agricultural land quality has been reduced due to the many uses of chemical fertilizers. Efforts to increase the productivity of food crops especially soy are also increasingly improved. Agricultural and housing waste is also more and more. Application of Liquid Organic Fertilizer from agricultural and residential waste on soybean productivity is done to help repair the physical structure and chemical soil that can also increase the productivity of soy by utilizing liquid organic fertilizer that comes from Agricultural waste and housing. This study used the complete Non-factorial randomized draft with each of the 3 repeated treatments, consists of 7 treatments for some Liquid Organic Fertilizers, that are POC

\section{PENDAHULUAN}

Pada saat ini pertanian organik perlu digencarkan kepada petani sebagai pelaku usaha pertanian, seluruh petani dapat menerapkan pertanian organik, bahkan terdapat peluang yang cukup besar bagi petani konvensional untuk menerapkan pertanian organic (Emiria dan Purwandari, 2014). Pupuk organik juga memiliki keunggulan terhadap lahan pertanian yaitu residu dari pupuk organik yang digunakan dapat dimanfaatkan bagi pertanaman selanjutnya (Aziz et al, 2016)

Pada tanaman kedelai, pemberian pupuk organik cair dapat memenuhi kekurangan hara makro maupun hara mikro yang mempengaruhi proses penyerapan mineral dan hara tanaman, memperkuat pertumbuhan tanaman karena tersedia dalam bentuk cair sehingga dapat dengan mudah diserap tanaman (Rahman, 2017) dan tanaman kedelai juga memiliki sifat yang responsif terhadap residu pupuk yang from vegetable waste + rice water, POC from water hyacinth + rice water, POC from kitchen food scraps, POC from banana stems + rice water, POC from banana stems, POC comes from water hyacinth, and POC comes from vegetable residues, the observed variables are plant height, number of leaves and number of pods per plant. Carried out on the ground practice of theMedan Agricultural Development Polytechnic Campus, from OctoberJanuary 2020. From the results of the study gained that the use of POC derived from a mixture of waste vegetables and water of rice laundry gives better results to the growth of plants, the number of leaves and the number of soybean pods, with values on the 4 MST, Plant height $49 \mathrm{~cm}$, number of leaves 49 strands and 213.7 number of pods.

terdapat dari tanaman sebelumnya (Subandi, 2013).

Penggunaan pupuk organik pada dasarnya tidak berpengaruh terhadap pertumbuhan tanaman, komponen hasil dan hasil biji kedelai serta tidak responsif pada fase pertumbuhan vegetatif maupun generatif (Pieter, Y dan M.J Mejaya, 2018). Bahan organik mengandung unsur $\mathrm{C}$ dan $\mathrm{N}$ dengan jumlah yang bervariasi. Pada kebanyakan tanah yang subur memiliki nicbah $\mathrm{C} / \mathrm{N}$ antara 1 sampai 11. Suatu tanah yang memiliki nisbah $\mathrm{C} / \mathrm{N}$ yang tinggi akan mengakibatkan mikroorganisme akan berkembang secara cepat dengan menggunakan nitrogen tanah sebagai sumber energi dan untuk berkembang biak serta tanah akan mengalami perubahan imbangan $\mathrm{C}$ dan N dengan cepat (Sutanto, 2019).

Bahan organik yang ditambahkan ke dalam tanah akan menjadi sumber energi dan makanan untuk berbagai mikroorganisme di dalam tanah yang selanjutnya akan mengalami 
proses dekomposisi untuk menghasilkan berbagai macam senyawa organik dan anorganik. Senyawa yang dihasilkan tersebut dimanfaatkan dalam proses pertumbuhan tanaman sebagai unsur hara dan senyawa pengatur pertumbuhan tanaman (Sutanto, 2012).

Perkotaan dan permukiman pada saat ini menunjukkan perkembangan terhadap sampah dan limbah yang meningkat secara dramatis, sebagian besar sampah merupakan sampah organik yang apabila didekomposisi dengan baik dapat dimanfaatkan sebagai pupuk organik (Sutanto, 2019). Air cucian beras juga dapat dijadikan sebagai POC karena mengandung bahan organik $2,245 \%, \mathrm{C} / \mathrm{N}$ ratio $81,38 \%$, P2O5 total $0,073 \%$ dan $\mathrm{K} 2 \mathrm{O}$ total $0,052 \%$ (Satriawi et al, 2019)

Karena banyaknya sumber daya sampah organik yang tersedia dan juga lahan pertanian yang mulai rusak akibat penggunaan dari bahan kimia yang berlebihan, maka penulis melakukan penelitian ini untuk dapat mengatasi hal tersebut yang diharapkan juga dapat meningkatkan produksi tanaman pangan khusunya kedelai.

\section{METODE}

Penelitian ini merupakan jenis penelitian kuantitatif. Penelitian ini dilaksanakan pada tanggal 14 Oktober 2019 sampai 20 Januari 2020 di lahan praktik kampus Politeknik Pembangunan Pertanian Medan.

Pada penelitian ini menggunakan kedelai varietas Anjasmoro. Persiapan lahan dilakukan dengan tiga tahap pengolahan lahan. Sebelum dilakukan penanaman, benih kedelai diberi perlakuan terhadap inokulan rhizobium yang berasal dari tanah bekas pertanaman kacang kedelai.

Alat yang digunakan dalam percobaan ini yaitu ember, pisau, botol (wadah untuk POC). Bahan yang digunakan yaitu EM4, gula. air bersih, air beras, sisa sayuran, batang pisang, eceng gondok, air kelapa,

Percobaan ini menggunakan Rancangan Acak Kelompok Lengkap yang terdiri dari tujuh perlakuan terhadap beberapa Pupuk Organik Cair, yaitu P1 (berasal dari sisa sayuran + air beras), P2 (berasal dari eceng gondok + air beras), P3 (berasal dari sisa makanan dapur), P4 (berasal dari batang pisang + air beras), P5 (berasal dari batang pisang). P6 (berasal dari eceng gondok), P7 (berasal dari sisa sayuran). Sebelum diaplikasi, Pupuk Organik Cair terlebih dahulu diencerkan dengan perbandingan $50 \mathrm{ml}$ POC dilarutkan kedalam 1 liter air.

\section{HASIL DAN PEMBAHASAN}

Tabel 1 menunjukkan bahwa pertambahan terhadap tinggi tanaman kedelai setiap minggu mengalami peningkatan. Pada Gambar 1, juga menunjukkan grafik pengaruh aplikasi pupuk organik cair terhadap tinggi tanaman kedelai pada 4 MST (Minggu Setelah Tanam) dengan hasil yang memiliki tinggi tanaman paling tinggi dengan diberi perlakuan P1 (sisa sayuran + air cucian beras) yaitu 49,0 $\mathrm{cm}$, diikuti dengan perlakuan P3 (sisa makanan dapur) yaitu $46,0 \mathrm{~cm}$, selanjutnya P2 (eceng gondok + air cucian beras) yaitu $41,7 \mathrm{~cm}, \mathrm{P} 6$ (eceng gondok) $40 \mathrm{~cm}, \mathrm{P} 7$ (sisa sayuran) $39 \mathrm{~cm}$, P4 (batang pisang + air cucian beras) $36,3 \mathrm{~cm}$ 
dan terpendek pada tanaman dengan diberi perlakuan P5 (batang pisang) 34,7 cm.

Perlakuan P1 adalah pupuk organik cair dengan bahan sisa sayuran dan air beras yang memberikan pengaruh pada parameter tinggi tanaman. Untuk mencukupi kebutuhan hara tanaman dapat juga dengan menambahkan limbah air cucian beras dapat mendukung pertumbuhan dan proses metabolisme tanaman (Rosmarkam et al., 2002). Pada tanaman kangkung umur 10 dan 20 HST, pengaplikasian limbah air cucian beras memberikan pengaruh terhadap pertumbuhan tinggi tanaman kangkung, hal ini diduga bahwa air cucian beras $100 \%$ dapat diserap dengan baik pada umur tanaman 10 dan 20 HST (Wardiah et al., 2014).

Tabel 1. Pengaruh Tinggi Tanaman Kedelai Terhadap Berbagai Perlakuan Pupuk Organik Cair (Keterangan "MST = Minggu Setelah Tanam”)

\begin{tabular}{ccccc}
\hline \multirow{2}{*}{ Perlakuan } & \multicolumn{4}{c}{ Parameter Tinggi Tanaman (cm) } \\
\cline { 2 - 5 } & 1 MST & 2 MST & 3 MST & 4 MST \\
\hline P1 & $12,7^{\mathrm{b}}$ & $20,5^{\mathrm{abc}}$ & $31,7^{\mathrm{ab}}$ & $49,0^{\mathrm{a}}$ \\
P2 & $11,4^{\mathrm{b}}$ & $18,0^{\mathrm{cd}}$ & $33,7^{\mathrm{a}}$ & $41,7^{\mathrm{bc}}$ \\
P3 & $11,8^{\mathrm{b}}$ & $16,7^{\mathrm{d}}$ & $30,0^{\mathrm{bc}}$ & $46,0^{\mathrm{ab}}$ \\
P4 & $11,2^{\mathrm{b}}$ & $22,5^{\mathrm{a}}$ & $28,3^{\mathrm{cd}}$ & $36,3^{\mathrm{cd}}$ \\
P5 & $12,7^{\mathrm{b}}$ & $19,0^{\mathrm{bcd}}$ & $26,7^{\mathrm{d}}$ & $34,7^{\mathrm{d}}$ \\
P6 & $5,7^{\mathrm{c}}$ & $20,7^{\mathrm{abc}}$ & $29,0^{\mathrm{bcd}}$ & $40,0^{\mathrm{bcd}}$ \\
P7 & $15,3^{\mathrm{a}}$ & $22,0^{\text {ab }}$ & $29,0^{\mathrm{bcd}}$ & $39,0^{\mathrm{cd}}$ \\
\hline
\end{tabular}

Dari pengamatan parameter jumlah daun terhadap perlakuan berbagai jenis POC pada 4 MST (tabel 2), perlakuan P1 (sisa sayuran + air cucian beras) memberikan jumlah daun yang lebih banyak dibanding perlakuan yang lain yaitu 49 helai, diikuti P3 (sisa makanan dapur) 32 helai daun, P2 (eceng gondok + air cucian beras) 30 helai daun, P7 (sisa sayuran) 23,7 helai daun, P5 (batang pisang) 17,0 helai daun, P4 (batang pisang + air cucian beras) dan P6 (eceng gondok) 7,3 helai daun. Kandungan Air Beras dan limbah sayur memberikan repon terhadap pertumbuhan daun yang signifikan. Ini diduga unsur yang terkandung di dalam air memberikan pengaruh terhadap pertumbuhan jumlah daun, hasil Penelitian Wulandari et. All., 2011 yang juga menjelaskan bahwa di dalam air cucian beras terdapat kandungan Nitrogen sebesar $0,015 \%$ dan Fosfor 16,.63\%, merupakan unsur makro yang dibutuhkan untuk pertumbuhan daun.

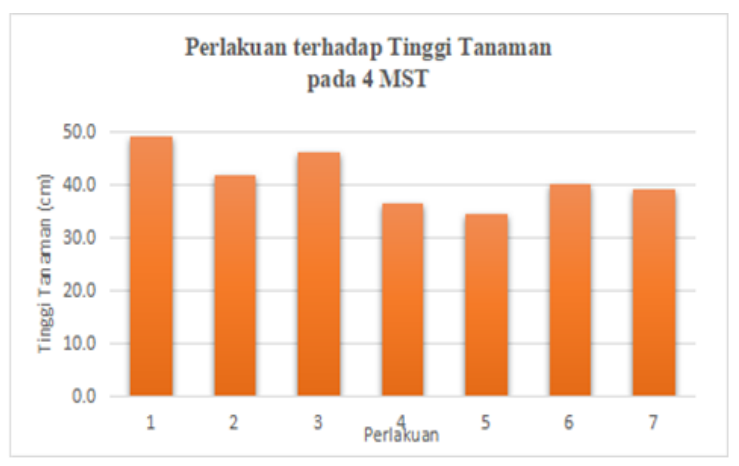

Gambar 1. Grafik Perlakuan Pupuk Organik Cair Terhadap Tinggi Tanaman Pada 4 MST

Pertumbuhan tanaman yang baik dapat meningkatkan pertumbuhan vegetatif tanaman seperti daun, dengan pemberian pupuk organik cair, pertambahan jumlah daun dari tanaman kedelai menunjukkan hasil yang bagus karena pupuk organik cair yang diberikan dapat dimanfaatkan oleh tanaman untuk tumbuh dan berkembang, hal ini sesuai dengan pernyataan dari Sabilu et al. (2015) bahwa perlakuan pupuk organik menghasilkan perbedaan nyata terhadap kadar unsur hara pada batang tanaman kedelai. 
Tabel 2. Pengaruh Jumlah Daun Kedelai Terhadap Berbagai Perlakuan Pupuk Organik Cair

\begin{tabular}{ccccc}
\hline & \multicolumn{4}{c}{ Parameter Jumlah Daun } \\
\cline { 2 - 5 } Perlakuan & 1 MST & 2 MST & 3 MST & 4 MST \\
\hline & & & & \\
\hline P1 & $7,7^{\mathrm{a}}$ & $19,3^{\mathrm{a}}$ & $32,7^{\mathrm{a}}$ & $49,0^{\mathrm{a}}$ \\
P2 & $4,7^{\mathrm{b}}$ & $12,7^{\mathrm{b}}$ & $23,0^{\mathrm{b}}$ & $30,0^{\mathrm{b}}$ \\
P3 & $4,0^{\mathrm{b}}$ & $10,3^{\mathrm{b}}$ & $14,3^{\mathrm{c}}$ & $32,0^{\mathrm{b}}$ \\
P4 & $2,0^{\mathrm{c}}$ & $3,3^{\mathrm{c}}$ & $6,0^{\mathrm{d}}$ & $7,3^{\mathrm{d}}$ \\
P5 & $4,0^{\mathrm{b}}$ & $9,7^{\mathrm{b}}$ & $15,7^{\mathrm{c}}$ & $17,0^{\mathrm{cd}}$ \\
P6 & $2,7^{\mathrm{c}}$ & $4,7^{\mathrm{c}}$ & $6,3^{\mathrm{d}}$ & $7,3^{\mathrm{d}}$ \\
P7 & $4,0^{\mathrm{b}}$ & $11,0^{\mathrm{b}}$ & $15,7^{\mathrm{c}}$ & $23,7^{\mathrm{bc}}$ \\
\hline
\end{tabular}

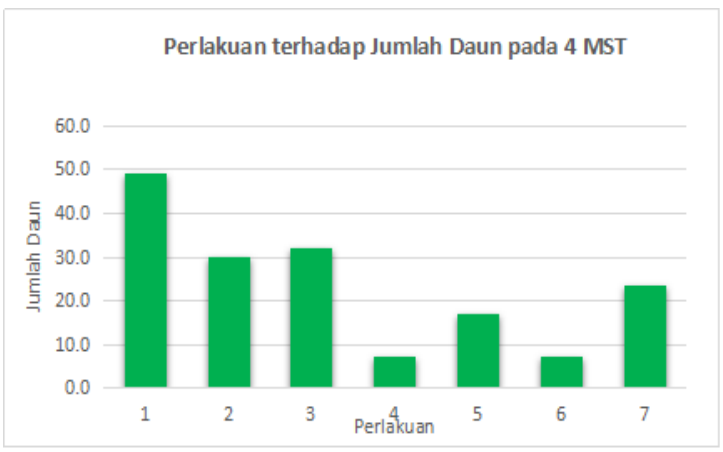

Gambar 2. Grafik Perlakuan Pupuk Organik Cair Terhadap Jumlah Daun Pada 4 MST

Dari hasil pengamatan didapat bahwa tanaman yang diberi perlakuan Pupuk Organik Cair berasal dari limbah sayuran dan cucian air beras memberikan respon yang baik terhadap munculnya jumlah polong. Hal ini ini diduga Air Beras memiliki kandungan Unsur Fosfor yang dibutuhkan oleh tanaman kedelai dalam pembentukan polong. Hal ini sesuai pernyataan Utami 2003 yang menyatakan Fosfor merupakan penyusun asam amino, koenzim NAD, NADP dan ATP, aktif dalam pembelahan sel dan merangsang pertumbuhan biji dan pembungaan. Sementara itu limbah sayur diduga berperan dalam memperbaiki media tanam, hal ini sesuai dengan pernyataan Sutanto (2019) yang menyatakan bahwa dengan menggunakan pupuk organik dapat memperbaiki sifak fisik tanah (struktur tanah), sifat kimia tanah (meningkatkan KTK dan ketersediaan hara) serta sifat biologi tanah (menambah energi bagi kehidupan mikroorganisme tanah).

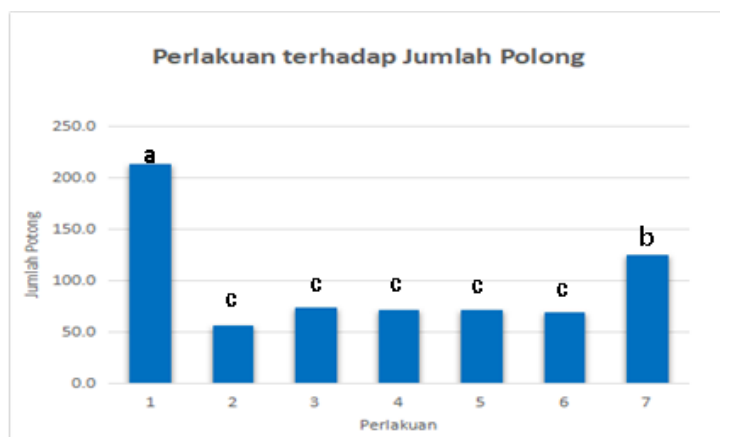

Gambar 3. Grafik Perlakuan Terhadap Jumlah Polong

Dari hasil penelitian diketahui bahwa jumlah polong yang paling banyak terdapat pada tanaman yang mendapat perlakuan POC limbah sayuran dan cucian air beras hal ini dikarenakan POC yang berasal dari limbah sayuran dapat diserap dengan cepat oleh tanaman sehingga dapat langsung digunakan dalam proses pertumbuhan tanaman kedelai. Hal ini sesuai dengan pernyataan Menurut Fauzan dan Susylowati (2016), yang menyatakan bahwa pupuk organik cair memberikan pengaruh yang sangat nyata terhadap jumlah polong total per tanaman, yang dapat dikarenakan penambahan konsentrasi POC yang tepat sangat berguna untuk memenuhi kebutuhan unsur hara baik makro maupun mikro bagi tanaman kedelai. Yunita et all, 2016 juga menyatakan bahwa dengan mengaplikasikan POC pada tanaman cabai 
merah maka unsur hara $\mathrm{N}, \mathrm{P}$, dan $\mathrm{K}$ serta unsur lain yang terkandung di dalam POC limbah sayuran dapat dengan mudah diserap oleh tanaman cabai merah sehingga proses fotosintesis dapat berjalan lebih optimal.

\section{KESIMPULAN DAN SARAN}

Dari percobaan yang dilakukan diperoleh kesimpulan, yaitu : Pupuk Organik Cair yang terbuat dari limbah sayuran dan air cucian beras lebih bagus daripada keenam POC lainnya untuk pertumbuhan tanaman kedelai; POC campuran limbah sayuran dan air cucian beras dapat memberikan tinggi tanaman kedelai sebesar 49,0 cm dan jumlah daun kedelai sebesar 49 helai daun pada 4 MST dan jumlah polong sebanyak 213,7 polong; POC campuran limbah sayuran dan air cucian beras dapat memberikan produktivitas kedelai yang lebih tinggi dibandingkan POC dari eceng gondok + air beras, POC dari sisa makanan dapur, POC dari batang pisang + air beras, POC dari batang pisang, POC dari eceng gondok dan POC dari sisa sayuran.

\section{UCAPAN TERIMA KASIH}

Peneliti ucapkan terima kasih kepada pihak - pihak yang telah berkontribusi dalam penelitian ini yaitu : 1) Jurusan Pertanian Polbangtan Medan yang telah memberikan bantuan dana dan dukungan, 2) Mahasiswa/i Jurusan Pertanian Polbangtan Medan khususnya angkatan 2017 yang tidak bisa disebutkan namanya satu persatu yang telah berkontribusi dalam membantu pelaksanaan penelitian, dan 3) Teman - teman yang telah memberikan kontribusi dan dukungan dalam penyusunan laporan.

\section{DAFTAR PUSTAKA}

Aulia Abdul Rahman, A. B., \& Sipayung, R. (2017). Respons Pertumbuhan Dan Produksi Tanaman Kedelai Terhadap Pemberian Pupuk Organik Cair Dan Mulsa. Jurnal Agroekoteknologi Universitas Sumatera Utara, 5(1), 85-92. https://doi.org/10.32734/jaet.v5i1.15084

Aziz, S. A., Melati, M., \& Ramadhani, E. (2016). The Study of Organic Fertilizers Application on Two Soybean Varieties in Organic Saturated Soil Culture. Journal of Tropical Crop Science, 3(1), 19-27. https://doi.org/10.29244/jtcs.3.1.19-27

Citra Wulandari G.M, Sri Muhartini, \& S. T. (2013). Pengaruh Air Cucian Beras Merah dan Beras Putih Terhadap Pertumbuhan dan Hasil Selada (Lactuca

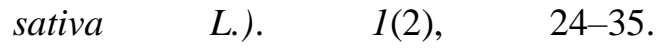
https://doi.org/10.22146/veg.1516

Emiria, F., \& Purwandari, H. (2015). Pengembangan Pertanian Organik di Kelompok Tani Madya, Desa Kebonagung, Kabupaten Bantul, Daerah Istimewa Yogyakarta. Jurnal Penyuluhan, $10(2)$.

https://doi.org/10.25015/penyuluhan.v10i 2.9919

Pieter, Y., \& Mejaya, J. M. (2018). Pengaruh Pemupukan Hayati terhadap Pertumbuhan dan Hasil Kedelai di Lahan Sawah. Penelitian Pertanian Tanaman Pangan, 2(1), 51-57. https://doi.org/http//dx.doi.org/10.21082/j pptp.v2n1.2018.p51-57

Rosmarkam, Nasih AWY. 2002. Ilmu Kesuburan Tanah. Kanisius. Yogyakarta. 46 hal

Sabilu, Y., Damhuri, \& Imran. (2015). Azotobacter sp., Mikoriza dan Pupuk Organik. Jurnal Biowallacea, 2(1), 153161. 
Satriawi, W., Tini, E. W., \& Iqbal, A. (2020). Pengaruh Pemberian Pupuk Limbah Organik Terhadap Pertumbuhan Dan Hasil Tanaman Mentimun (Cucumis Sativus L.). Jurnal Penelitian Pertanian Terapan, $19(2), \quad 116$. https://doi.org/10.25181/jppt.v19i2.1407

Subandi. (2013). Peran dan pengelolaan hara kalium untuk produksi pangan di Indonesia. Jurnal Pengembangan Inovasi Pertanian, 6(1), 1-10.

Sutanto, R. (2012). Pertanian Organik : Menuju Pertanian Alternatif dan Berkelanjutan. Kanisius, Yogyakarta

Sutanto, R. (2019). Penerapan Pertanian Organik : Pemasyarakatan dan Pengembangannya. Kanisius, Yogyakarta

Walid, L. F., \& Susylowati. (2016). Pengaruh Konsentrasi Pupuk Organik Cair (POC) Terhadap Pertumbuhan dan Hasil Beberapa Varietas Tanaman Kedelai (Glycine $\max$ (L.) Merill). ZIRAA'AH, 41(1), 84-96. https://media.neliti.com/media/publicatio ns/224056-pengaruh-konsentrasi-pupukorganik-cair.pdf

Wardiah, L. \& H. R. (2015). Potensi Limbah Air Cucian Beras Sebagai Pupuk Organik Cair Pada Pertumbuhan Pakchoy (Brassica rapa L.). Jurnal Biologi Edukasi, 6(1), 34-38.

Yunita, F., Damhuri, \& Sudrajat, H. W. (2016). Limbah Sayuran Terhadap Pertumbuhan dan Produksi Cabai Merah (Capsicum annuum L.). Jurnal AMPIBI, 1(3). 